\title{
Sultan Aqung

\section{Notary Liability for Making Assets Based on False Letters Delivered by Company}

\author{
Muhamad Ridho ${ }^{*}$, Akhmad Khisni ${ }^{* *}$ and Amin Purnawan ${ }^{* * *}$
}

*) Student of Master of Notary Law, Faculty of Law, Universitas Islam Sultan Agung Semarang, E-mail: ridhomangilala@gmail.com

${ }^{* *}$ Lecturer Master of Notary Law, Faculty of Law, Universitas Islam Sultan Agung Semarang, Indonesia

$\left.{ }^{* * *}\right)$ Lecturer Master of Notary Law, Faculty of Law, Universitas Islam Sultan Agung Semarang, Indonesia

\begin{abstract}
This study aims to determine the obstacles of the notary in identifying the truth of the letter or document submitted by the tappers. The type of research used in this research is juridical empirical research, which is research that is carried out by examining the applicable legal provisions and what happens in society. This research approach method is a sociological and statutory approach. The data in this study are library data and field research. The data were obtained from interviews and with sources, namely 03 (three) Notaries in Kendari City, and supporting data obtained through literature and document studies. The data collection techniques that the researcher will use are interviews and document studies. The results of this study indicate that the notary is only formally responsible and has no obligation to materially prove the correctness of the documents shown by the informants. Notaries can only be held accountable if the Notary is proven to have committed a violation as stipulated in Articles 84 and 85 of the UUJN and the notary's code of ethics, which can be held responsible criminally, civil and administratively. Barriers can be in the form of: dishonesty in the correctness of information and/or documents submitted; technological engineering through scanning and editing of submitted documents, client demands for resolving the deed quickly, lack of extracting information/information from the notary to the parties; the high quantity of notary work which causes inaccuracy in making deeds, and the emotional closeness of the notary to the tappers. Legal protection for notaries in carrying out their positions in relation to the correctness of documents submitted by the tappers includes: Preventive Legal Protection, namely: Notaries carry out their positions by always referring to statutory regulations and the notary's code of ethics; Supervision and routine examination of the notary honor council. Meanwhile, repressive legal protection, namely: legal protection for notaries in the event of a case or party reporting a notary on an alleged violation of the law in a deed made with the approval of the Notary Honorary Council which is for the benefit of judicial proceedings, investigations of public prosecutors or judges with the approval of the Notary Honorary Council.
\end{abstract}

Keyword: Liability; Assets; False Letters; Delivery. 


\section{Introduction}

The notary as an official has the authority to make authentic deeds regarding all actions, agreements, and provisions required by laws and regulations and/or those interested in being stated in the authentic deed, guarantees certainty of making deeds, provides grosse, copies and excerpts of deeds, all of which, as long as the deeds are drawn up, there is no assignment or exclusion to other officials or other people or other people determined by law as provided for in Article 15 paragraph 1 of Act No. 30 of 2004 concerning the Position of a Notary in conjunction with Act No. 02 of 2014 concerning Amendments to Act No. 30 of 2004 concerning the Position of Notary (here in after referred to as UUJN).

Notaries also have the authority to assist the government in serving the public in ensuring legal certainty, order and protection through authentic deeds made by or in front of them, given that authentic deeds are made by or in front of them, considering authentic deeds are the strongest evidence and have juridical value. Essential in every legal relationship in the event of a dispute in community life. An authentic deed made by a notary is a means of proof to state the existence of a legal act committed by the tapper. As evidence, authentic deeds are said to have perfect evidentiary power because they have three evidentiary powers, namely external evidentiary power, formal proving power, and material proof strength. The strength of external proof (uitwendige bewijskracht) is the ability of an authentic deed to prove its validity as an authentic deed that is born in 
accordance with legal regulations regarding the requirements of an authentic deed. The strength of formal proof (formele bewijskracht), namely the ability to provide certainty that an event and facts mentioned in the deed were indeed carried out, related to the date or time of manufacture, the identity of the tappers, the signatures of the tappers, witnesses, and notary, place of manufacture deeds, as well as information or statements seen, witnessed, heard or conveyed by the audience. The strength of material proof of a deed. ${ }^{1}$ In carrying out his duties and positions, notaries who are authorized to make authentic deeds can be held responsible for their actions in accordance with article 1 number 1 UUJN. This responsibility is the basic willingness to carry out its obligations. The notary's responsibility includes the material correctness of the deed he makes. The notary is not responsible for the negligence and errors of the contents of deeds made before him, but the notary is only responsible for the formal form of authentic deeds required by law. Any authority given to a notary must be based on its legal rules as a limit so that the position can run properly and does not conflict with other office powers. Thus, if a notary commits an action outside the predetermined authority, can be categorized as an act that violates authority. So the notary deed is not legally binding or enforceable.

\footnotetext{
1 Adjie, Sjaifurrachman and Habib. (2011). Aspek Pertanggung jawaban Notaris Dalam Pembuatan Akta. Bandung : Mandar Akta. p. 116-118.
} 
In practice, many have found, if there is a notary deed in dispute by tappers or other third parties, then the notary is often withdrawn as a party who participates in or helps commit a criminal act, namely making or providing information Notary is a legal profession so that the notary profession is a noble profession (Nobile officium). Deeds made by notaries can be a legal reason for the status of a person's property, rights and obligations. Errors in deeds made by a notary can result in the loss of one's rights or the burden of someone on an obligation. Therefore, in carrying out their duties, notaries must comply with the various provisions as stated in the Law on Notary Position. The term General Officer is a translation of the term Openbare Amtbtenare which is contained in Act No. 30 of 2004 concerning the Position of a Notary which was promulgated on November 6, 2004 in the State Gazette of the Republic of Indonesia Number 117 (UUJN) JO. Law of the Republic of Indonesia Number 2 of 2014 concerning Amendments to Act No. 30 of 2004 concerning the Position of Notary which was promulgated on January 15, 2014 State Gazette of Indonesia of 2014 Number 3 (Amendment Law on UUJN). In Article 1 number 1 of the Law on UUJN which confirms that a Notary is a public official who has the authority to make authentic deeds and other powers as referred to in this Law.

In this case, the Notary, intentionally or unintentionally, together with the parties/parties to make deeds with the intent and purpose of benefiting certain parties or parties or harming others, must be proven in court. Notary deed which is made according to the wishes of the interested party to ensure or guarantee 
the rights and obligations of the public official (Notary). The notary is obliged to include in the deed what has really been understood in accordance with the wishes of the informer and read to the informer about the contents of the deed. The statement or statement of the parties by the notary shall be stated in the notary deed. So that in civil cases, authentic deeds are binding and compelling evidence. ${ }^{2}$ Notary deeds have perfect evidentiary power so that if there is a person or party who judges or states that the deed is untrue, then the person or party assessing or declaring it is obliged to prove his assessment or statement in accordance with the rule of law. ${ }^{3}$

However, it is not a secret that notaries are often summoned to court to provide information on deeds or documents that are in dispute. This raises the question of whether the Notary has acted not in accordance with the Legislation and the Notary's Code of Ethics or is there an error either intentionally or unintentionally by the parties or one of the parties to attempt to commit fraudulent acts so as to cause harm to the other party by providing information and incorrect documents. The UUJN stipulates that when a Notary in carrying out his/her job duties has committed a violation that causes a deviation from the law, the Notary may be subject to sanctions, namely in the form of civil, administrative or Position Code of Ethics for Notary

\footnotetext{
${ }^{2}$ Anshori, AbdulGhofur . (2009). Lembaga Kenotariatan Indonesia. Perspektif Hukum dan Etika. Yogyakarta : UII Press. p. 46.

${ }^{3}$ Adjie, Habib. ( 2008). Hukum Kenotariatan di Indonesia-Tafsiran Tematik Terhadap UU No. 30 Tahun 2004 Tentang Jabatan Notaris. Bandung : Refika Aditama. p.14.
} 
Even though the UUJN does not mention the application of criminal sanctions, a legal action against violations committed by a notary and civil sanctions can then be withdrawn and qualified as a criminal act committed by a notary which explains the evidence of involvement in deliberately committing the crime of falsifying authentic deeds. In whatever form the error is proven, it becomes the notary's obligation to account for the deed drawn up by or in front of him who reap the error. In UUJN, there are only civil and administrative sanctions where these sanctions are deemed ineffective for those who feel they are disadvantaged.4 As a result, there is a norm vacuum in the Law on amendments to the Law on Notary Position relating to the responsibility of the Notary in making deeds based on data and information falsified by the Person.

Based on the interesting reality that is poured in the background, it encourages the writer to raise a title that is will be discussed in this study with the title

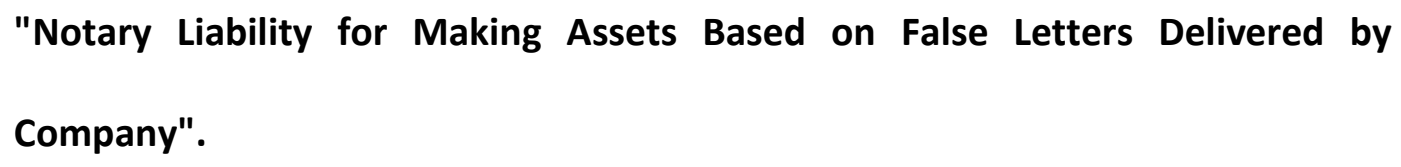

2. Research methods

This research approach method is sociological approach and legislation. The data in this study are library data and field research.

\footnotetext{
${ }^{4}$ Nurkasanah, Ida. (2015). Pertanggungjawaban Notaris Terhadap Akta Otentik Yang Di buat Dihadapannya (Studi Terhadap Notaris Di Kota Semarang). Semarang. p. 19-20.
} 


\section{Results and Discussion}

What are the obstacles for the notary in identifying the correctness of the letter or document submitted by the tappers?

Whereas the authentic deed is proof of the truth of what has been seen, heard and done by the notary. Everything about the date, where the deed was made, and the correct signature of the Notary. The notary deed becomes evidence that all statements contained therein are given by the notary. And the party deed becomes evidence from a notary which contains a statement or statement on their signature.

Notary deed can only prove the truth of what the notary sees and does. If the notary hears the statement of the party concerned, it only means that it is certain that the party concerned explains this, regardless of the truth of the contents of the statement. In a formal sense, the notary deed proves the truth and what is witnessed, namely what is seen, heard and also carried out by the notary himself as a notary in carrying out his position.

Furthermore, in a formal sense, the correctness of the date and deed is guaranteed, the truth and signature of the deed, the identity and the witnesses present, as well as the place where the deed was made.

According to Muhammad Ishak, ${ }^{5}$ One of the things that the notary must be aware of, is document falsification using scanning and editing. It is undeniable

\footnotetext{
${ }^{5}$ Interview with Muhammad Ishak, SH, M.Kn., MM, Notary and PPAT in Kendari City, on January 21, 2021.
} 
that the increasingly sophisticated technology makes a technology literate person who can abuse his skills for things that are against the law. In the context of documents shown to the Notary Public, for example documents in the form of Power of Attorney, land title, proof of tax payment, deed of approval and power of attorney, notarial deed, legalized deed and other documents that have the potential to be edited.

Further stated by Muhammad Ishak, ${ }^{6}$ Whereas in the past there were many cases involving the parties requesting their own transfer tax documents for the sale and purchase of land and buildings to be purchased. Then scaning is carried out and continued editing of the documents and proof of tax payment, as if the tax on the sale and purchase transaction has been paid. Intentionally using fake or falsified documents and proof of payment by changing the data in it. In this case in the past, before banking transaction data had not been verified online through the NTPD (Regional Revenue Transaction Number) or NTPN (State Revenue Transaction Number), this mode was quite widely practiced. Whatever it involves involving parties involved in the process of paying taxes, transfers, or registering the land. But for now, with layered verification.

Especially for a notary, a notary should be required to be able to visually identify and distinguish the document's authenticity. However, for certain restrictions, where visually the document is very similar to the original, and the Notary cannot distinguish it, which the Notary has maximally identified, then in such

${ }^{6}$ Ibid. 
conditions, the Notary cannot be held accountable. As a Notary Public has no obligation to prove materially the documents shown.

According to Mifta Husabri, ${ }^{7}$ In general, the Notary Public is not responsible materially for the contents of the documents shown by the Interviewer. Notaries only formally check every document presented by the Interviewer. However, the notary should do a filter/screening related to the accuracy of the document. The notary generally knows the general characteristics of the document and the official who is authorized to produce/issue the document. For example, a certificate of being unmarried and a certificate of different names, it is generally known that the letter was issued from the kelurahan/village office, of course the letter has a letterhead number, letter number, date of letter, signature of the village head/to the village, and a stamp. position. The same is the case with the Marriage Certificate issued by the Office of Religious Affairs,

Furthermore, according to Miftah Husabri, ${ }^{8}$ it would be very odd, if suddenly a Respecter came with a Marriage Certificate issued by the Civil Registry Office, which by law nomenclature is not within his authority. Likewise with other documents, which are generally known along with the characteristics of formal forms. If the notary finds irregularities in the form of the document/letter, the notary should question the informant regarding these irregularities.

${ }^{7}$ Interview with Miftah Husabri, SH, M.Kn. Notary and PPAT in Kendari City, on January 21, 2021.

${ }^{8}$ Ibid. 
As stated by Rayyan Riadi, ${ }^{9}$ that the Notary is not materially responsible for the contents of the documents shown by the Interviewer. Notaries only formally check every document presented by the Interviewer. However, the notary should do a filter/screening related to the accuracy of the document. The notary generally knows the general characteristics of the document and the official who is authorized to produce/issue the document.

Based on the explanation from the interview results above, the researcher concludes that in general the things that are obstacles for the notary to prove the correctness of the documents shown by the parties are as follows:

1. Dishonesty of information and/or letters submitted to notaries.

2. The advancement of technology with sophisticated document forgery, which uses scanning (scanning documents) and editing (changing the contents of the letter). Documents in the form of Power of Attorney, land title, proof of tax payment, deed of approval and power of attorney, are now easily scanned and their contents and information are changed.

3. There is no inspection by the local lurah/village office to ascertain the documents that were issued, for example a certificate of not yet married or a certificate of different names.

4. Notaries who lack accuracy in finding information and sorting documents related to deeds to be made.

5. Notaries who are less up-to-date in developing their knowledge about notary.

${ }^{9}$ Interview with Rayan Riadi, SH, M.Kn. Notary and PPAT in Kendari City, on January 21, 2021. 
6. The client forced the deed to be made and paid a large enough honorarium so that he no longer checked the documents that were under by the tappers.

7. There is an emotional relationship between the notary and the attorney, for example friends or family relations, who want to make a deed by imposing their will by violating standard operating procedures in making deeds.

8. The high quantity of notary work that is not accompanied by good office governance is not uncommon between notaries and staff who do not have good communication, so that many documents are not screened properly.

\section{Closing}

Based on the results and interviews conducted by the author, if it is related to formal proof theory, this evidence guarantees the truth of what is contained and is contained in the deed, regarding the statements and letters that are below and the signatures of the parties. With the strength of this formal proof in an authentic deed it is proven that the public official or the notary concerned has stated in writing, as what is stated in the deed regarding the truth of what is described in the deed as something that is done and witnessed in carrying out that position. Insofar as the notary, on the basis of his belief in the notary's formal evidence, has no right to find out the truth of the material content that is under the stage. 
The notary should carry out a thorough examination of all documents submitted to him, accompanied by asking for information from the informant regarding the contents of the document, in which case there are irregularities regarding the documents and information submitted by the informer and may refuse to continue the deed drafting stage

\section{Referencess}

Books:

[1] Adjie, Sjaifurrachman and Habib. (2011). Aspek Pertanggung jawaban Notaris Dalam Pembuatan Akta. Bandung : Mandar Akta.

[2] Anshori, AbdulGhofur. (2009). Lembaga Kenotariatan Indonesia. Perspektif Hukum dan Etika. Yogyakarta: UII Press.

[3] Adjie, Habib. ( 2008). Hukum Kenotariatan di Indonesia-Tafsiran Tematik Terhadap UU No. 30 Tahun 2004 Tentang Jabatan Notaris. Bandung: Refika Aditama.

[4] Nurkasanah, Ida. (2015). Pertanggungjawaban Notaris Terhadap Akta Otentik Yang Di buat Dihadapannya (Studi Terhadap Notaris Di Kota Semarang). Semarang.

Interview:

[1] Interview with Muhammad Ishak, SH, M.Kn., MM, Notary and PPAT in Kendari City. 
[2] Interview with Miftah Husabri, SH, M.Kn. Notary and PPAT in Kendari City.

[3] Interview with Rayan Riadi, SH, M.Kn. Notary and PPAT in Kendari City. 